\title{
THE STUDY OF THE INTERSECTION BETWEEN FOOD FRAUD/ADULTERATION AND AUTHENTICITY
}

\author{
Aleksandra Kowalska ${ }^{1}$ \\ ${ }^{1}$ Department of Quality and Knowledge Management, Faculty of Economics, Maria Curie-Skłodowska University \\ in Lublin, pl. Marii Curie-Skłodowskiej 5, 20-031 Lublin, Poland
}

To cite this article: KOWALSKA ALEKSANDRA. 2018. The Study of the Intersection Between Food Fraud/Adulteration and Authenticity . Acta Universitatis Agriculturae et Silviculturae Mendelianae Brunensis, 66(5): 1275-1286.

To link to this article: https://doi.org/10.11118/actaun201866051275

\begin{abstract}
The first purpose of this paper is to collate and conceptualize two problems: food fraud/adulteration and food authenticity. The second aim is to investigate students' understanding of these concepts and their implications for consumers and producers (processors and/or farmers) to include food fraud course in university programme for business majors. In the theoretical part of the paper, the cognitive-critical analysis of the world's literature was applied; the analysis was enriched with instantiations coming from Polish economy, market issues and legislative framework. In the empirical (applicable) part, questionnaire survey was conducted among students of Economics Faculty at Polish university in 2016. Since food supply chains are more and more vulnerable to fraud, the issue has been getting significance rapidly. Both food fraud/adulteration and food authenticity may be treated in terms of instruments that entrepreneurs have in their hands while trying to succeed. The point is that consumers should be aware of these problems, appropriate educational program including university syllabus would help to raise this awareness. The surveyed students' understanding of the phenomenon is quite appropriate. The proposition is to conduct a social campaign covering researched issues. Knowledgeable consumers impose additional pressure on food industry to become more disciplined. The original contribution of this paper to theory is showing the intersection between food fraud/adulteration and authenticity concepts and recognising Polish students' perception of these issues.
\end{abstract}

Keywords: food fraud, food adulteration, food authenticity, consumer, EU Protected Food Name Scheme, Poland

\section{INTRODUCTION}

Food fraud/adulteration and food authenticity are, alongside food standard, food assurance, food safety, food quality, food crime, food defence and food protection, key aspects of food integrity (Manning, 2017; Wang et al., 2017). Both food fraud (including fraudulent adulteration) and food authenticity can be treated in terms of instruments that entrepreneurs have in their hands while trying to succeed. The consumer is a food supply chain participant that is probably influenced the most by ensuring food integrity.

Food fraud is illegal deception for economic gain using food (Spink et al., 2016). Food fraud can be committed along the whole supply chain, by suppliers, food manufacturers, retailers and importers (Johnson, 2014). Food fraud is a broader term than both economically motivated adulteration 
of food (EMA) and the more specific general concept of food counterfeiting (Spink and Moyer, 2011). A holistic perspective on food fraud includes acts such as: adulteration, tampering, theft, diversion, unauthorized production, and counterfeiting (Moyer et al., 2017). The Global Food Safety Initiative (GFSI) has adopted a definition of food fraud by Spink: a collective term encompassing the deliberate and intentional substitution, addition, tampering or misrepresentation of food, food ingredients or food packaging, labelling, product information or false or misleading statements made about a product for economic gain that could impact consumer health (Spink, 2014; Spink and Moyer, 2011). Adulteration can be defined as the addition of an undeclared material into a food item for economic gain (Spink and Moyer, 2013). Following BRC Global Standard for Food Safety v7 from 2015, food is adulterated while a component of the finished product is fraudulent (Manning and Soon, 2016). Silvis et al. (2017) claim that adulteration is the preparation of foods for sale by replacing valuable with less valuable ingredients or constituents. As a result of official controls in the food sector, adulteration of food is one of the most measurable and one of the most detectable act classified as food fraud. On the basis of Polish food law, food adulteration actually comes down to mislabelling (The Act on the Safety..., 2006; The Act on the Commercial..., 2000).

Food fraud has been getting significance rapidly. Since food fraud is seemingly becoming a bigger and more frequent problem, it is continuously taken into consideration in organizational, regulatory and industrial activities all over the world (Spink et al., 2016). The shift in focus from risk to vulnerability is due to the nature of food fraud (Spink, 2014). The prevention of an adulteration incident, prior to retail, costs less than dealing with a large foodborne disease outbreak (Davidson et al., 2017). Thus managing food fraud/adulteration should be integral to food supply chain management and not just an afterthought in the wake of an incident. However, food business operators seldom get involved in such practices. Food industry is starting making efforts to address food fraud separately from food safety and food defence. Since risks in food safety are typically unintentional and carry a public health hazard; risks in food defence come from intentional acts with the intent to harm; risks in food fraud are intentional but without an intent to harm human health. However, food fraud may have unintended health related consequences (Spink et al., 2017).

FSSC 22000 (Food Safety System Certification) Version 4, HARPC (Hazard Analysis and Risk-based Preventive Controls) and TACCP (Threat Assessment Critical Control Points) seem to be essential within food industry standards with regard to fraud. Since the timeline for implementing HARPC is relatively short (from 1 to 3 years after publication of the final rules for Food Safety Modernization Act, FSMA (Grover et al.,
2016) and the rules encompass importers of food for the US market, growing popularity of such standards can be expected. Another reason for this prediction is that food supply chains are more and more vulnerable to fraud as a result of globalisation, liberalization of trade, incoherent food laws within countries and regions, inadequate legislation, ineffective functioning of public food control institutions, long and complex food supply chains, growing anonymity of people running food businesses in the time of internet trade expansion, market pressure to reduce food prices, scientific and technological progress advantageous for fraudsters and so on (EC, 2013; Marvin et al., 2016).

PAS 96 guide, published in Great Britain in 2014, aims to assure food authenticity by minimizing the chance of an attack and mitigating the consequences of a successful attack (resulting in intentional adulteration of food). The question is if the concept of 'authentic food products' is opposite to the concept of 'food fraud/adulteration'. Charlebois et al. (2016) claim that an authentic finished food product has to comply with labelling regulations, principally in terms of ingredient composition, production protocols and practices, technology and genetic identity. Vinci et al. (2013) define authentication of food product as the procedure by which it is verified that the product matches the statements on the label, and that it conforms to what is established by regulations. This testing process includes analysis of the ingredients, determination of the geographical origin and species, and examination of the production methods. High costs and limited availability of quick, effective and reliable analytical methods used to verify the authenticity and traceability of some foodstuffs (e.g. seafood) is a problem (Leonardo et al., 2016).

A rapidly growing number of foodstuffs and growing competitiveness, especially in transition countries like Poland, have caused expanding the concept of 'food authenticity'. Authenticity of food has become a source of competitive advantage. Śmiechowska highlighted authenticity as a main attribute of traditional and regional food. This food stands out from other types of food because of its authenticity while 'authentic' means here 'consistent with the original, the taste remembered from childhood, often certified' ('́miechowska, 2014). It is worth saying that traditional and regional food is particularly important for some European regions (including Poland) and their agricultural and rural development.

The first aim of the paper is to collate and conceptualize two problems: food fraud/adulteration and food authenticity from the micro-economic point of view. The second aim of the paper is to investigate the understanding of the issue of food fraud/ adulteration and food authenticity among students of Economics Faculty at medium publicly funded university in Poland to include food fraud course in university programme 
for business majors. Raising students' awareness of food fraud/adulteration and authenticity issues should lead to spreading knowledge in this subject in their future workplaces. Moreover, it is highly probable that the diet of university students (usually living outside their family houses) consists of highly processed, compound food that is more vulnerable to fraud/adulteration (Cavin et al., 2016; Hines and Murphy, 2016; PwC, 2017). Thus raising their awareness of food fraud/adulteration and authenticity issues is justified. Examining students' knowledge and awareness of the phenomenon should be helpful in developing actions to increase customer interest in the quality and safety of purchased food, in developing an information/education programme on food fraud/adulteration and a promotion programme on food authenticity. This forms the research rationale for the survey.

Materials and Methods

The first part of the paper is the review part. The second part of the paper is based on a survey of young (mainly Polish) consumers who voluntarily participated in the study. Paper questionnaires were handed over to 127 students of Economics Faculty. Determinant factors of the decision on choosing the students for the research were: (1) there was a plan to offer students majoring in Logistics and/or Management a food fraud course; (2) students should have a relatively higher state of knowledge and analytical skills comparing to an average consumer. Data were collected during a period of one week in May 2016. 78 respondents were majoring in Management and 49 respondents were majoring in Logistics. $33 \%$ of sophomores majoring in Logistics were investigated and 50\% of sophomores majoring in Management were surveyed. The respondents majoring in Management were in the age of 18-23, with a mean average of 20,9 . Men comprised $33,3 \%$ of the group and women comprised $66,7 \%$ of the group. The respondents majoring in Logistics were in the age of $18-24$, with a mean average of 20,6 . Men comprised $24,5 \%$ of the group and women comprised $75,5 \%$ of the group.

The survey was conducted using six open-ended questions helpful in assessing the students' perception of food fraud/adulteration and food authenticity issues as follows:

1. What are your connotations with the term 'food fraud/adulteration'?

2. What does food fraud/adulteration bring to a consumer?

3. What does food fraud/adulteration bring to a producer (processor and/or farmer)?

4. What are your connotations with the term 'authentic food product'?

5. What does food authenticity bring to a consumer?

6. What does food authenticity bring to a producer (processor and/or farmer)?

The questionnaire was developed in Polish. $85 \%$ of the respondents were Polish and $15 \%$ of the surveyed students were Ukrainian (studying in Polish).
Students of Management most probably have not attended classes where they were supposed to acquire knowledge in food fraud, food adulteration and food authenticity issues. Students of Logistics have attended a lecture on Food Quality Management and a lecture on Commodity Science given by the author of the paper, but they have not learned about researched issues during the lectures. The author offered a lecture on food fraud/adulteration later in the future. Since there are significant differences between curricula for these two fields of study, a question is if the perception of researched issues is the same within two surveyed groups of students.

\section{RESULTS}

\section{Food fraud/adulteration: background}

Food fraud often leads to adulteration of food and to a public health threat (Spink and Moyer, 2011). Adulteration of food has always been an important issue regarding public health, consumer rights and business ethics. Some US literature makes a distinction between contamination and adulteration of food. Contamination is often considered in terms of an accidental, unintentional activity while adulteration is used to define all intentional and deliberate activities whether motivated by economic gain (EMA) or not (ideological/behavioural motivation) (Lipp, 2015; Manning and Soon, 2016). Every consumer may be subjected to this sort of cheating and in this way may lose his money and/or health. The consumer is a weak point of the food supply chain because of his/her limited capability of food fraud detection. Emerging food fraud-related enterprise risks are more and more important for decision makers. A common goal of governments and business managers and a priority is not to catch food fraudsters but to prevent food fraud incidents. Governments and standardization institutions have already noticed that deliberate adulteration of food has become an issue (Shears, 2010; Spink and Moyer, 2011).

The horsemeat scandal of 2013 proved the need for new organizational solutions covering food fraud, especially that fraudulent practices not generating public health risks are falling outside the scope of the Rapid Alert System for Food and Feed (RASFF). In response to the horsemeat crisis, the EU Food Fraud Network (EU FFN) was set up in 2013 and the Administrative Assistance and Cooperation System (AAC) was developed in 2015. Since then, cases of violation of EU food law with cross-border impact may be exchanged among Member States in the AAC system. At the same time, the European Commission (EC) developed four criteria to distinguish whether a case should be considered as food fraud or other non-compliance: (1) violation of the EU law; (2) intention; (3) economic gain; (4) deception of customers (EC, 2016). 
Food fraud is being included in more and more international laws and regulations as well as industry certification and standards. The well-known HACCP standard (Hazard Analysis Critical Control Point) has been proven to be effective against accidental contamination and insufficient against deliberate actions, including fraud (BSI, 2014). The US government introduced HARPC under FSMA finally in 2015. FSMA reform aims to ensure safety of US food supply by shifting the focus from responding to contamination to preventing it (http://www. fda.gov / Food / GuidanceRegulation / FSMA). HARPC includes planning for potential terrorist acts and/or intentional adulteration and food fraud. If an enterprise has an effective HARPC plan in place, it is also in compliance with HACCP mandates (www.harpc.com). The British FSA (Food Standards Agency) and DEFRA (Department for Environment, Food and Rural Affairs), together with the British Standards Institution and other organizations (Heineken UK, J Sainsbury plc, McDonald's Europe, Tesco plc, etc.) have had a significant input in publishing PAS 96:2014 guide. The purpose of PAS 96 is to guide food business managers through approaches and procedures to improve the resilience of supply chains to fraud and other forms of deliberate actions. PAS 96 describes TACCP System, a risk methodology which aligns with HACCP, but has a different focus (BSI, 2014). In 2014 GFSI presented their direction for including food fraud in their Food Safety Management System. They shifted their focus from risks to vulnerabilities and defined the Food Safety Management Umbrella to include three separate pillars that will need to be addressed individually: HACCP (hazard/food safety), TACCP (threat/food defence) and VACCP (vulnerability/food fraud). GFSI emphasizes that there is efficiency in building on the very familiar HACCP concepts since it is widely accepted and implemented (Spink, 2014). In December 2016, FSSC 22000 released their Version 4 which explicitly addressed and emphasized food fraud prevention. Aligned with GFSI, the standard requires a separate food fraud vulnerability assessment and prevention strategy for all types of fraud, all products, and across the whole food supply chain. It is important to have a separate assessment for food fraud and another for food defence (Spink, 2016). Risk and vulnerability assessment of food fraud is required by emerging regulations and industry standards as a prerequisite to countermeasures and decision-making systems. In 2016 Spink, Moyer and Speier-Pero developed the Food Fraud Initial Screening model (FFIS) which provided a simple method to begin reviewing and document emerging risks (Spinket et al., 2016). FFIS is an enterprise-wide, top-down, pre-filter step conducted before a full food fraud vulnerability assessment. EC has been addressing food fraud and stating a focus on prevention quite recently. The proof of this is the expansion of the RASFF System to include 'adulteration and fraud'.
Polish Act on the Safety of Food and Nutrition and the Act on the Commercial Quality of Agricultural and Food Products defining fraudulent adulteration of foodstuffs concentrate on mislabelling, mostly regarding a list of ingredients. The point is that a food fraud/adulteration act endangers safety of foodstuffs and/or consumers' interests (in terms of health and economic safety). Polish food control institutions (Agricultural and Food Quality Inspection, IJHARS and Trade Inspection, IH) make administrative decisions considering food fraud/adulteration public. The information publicized on the IJHAR-S webpage contains the following elements: the legal basis of the decision, number and date of the decision, the name of a fraudulent product, the number of production batch and the date of production, batch volume, confirmed irregularities, the name of an entity which placed the food on the market (Kowalska et al., 2018). However, another survey conducted among 103 administration employees of the university in September 2016 showed that consumers were not familiar with an easy access to this information. Thus, the question is if this tool is efficient. Probably it is not. The outcome of Polish official food control system activities need to be publicized and consumers need to be educated in the field of food fraud/adulteration. RASFF also seems to be unknown and hard to understand for an average consumer.

Another point is that Polish food business operators seem to have problems with implementing Regulation (EU) No 1169/2011 on the provision of food information to consumers and other national regulations regarding labelling of foodstuffs. The author has interviewed 20 owners of small food businesses exhibiting at INTEFO trade fairs - Small Scale Food Processing Technology and Innovations run in Lublin in November 2016. 19 of them claim that regulations on labelling are not clear and they were fined for mislabelling in the past. Thus, mislabelling does not always have to be economically motivated. It is not seldom that small food business operators have insufficient knowledge about labelling their products and cannot afford to pay for expert knowledge and experience in this field.

\section{Food authenticity: background}

The background for food authenticity has more technological rather than economic overtones. Confirming food authenticity requires the use of sophisticated tools and advanced human skills and knowledge. Analytical methods used to confirm food authenticity are not always easily accessible and quite often too expensive (Leonardo et al., 2016; Vinci et al., 2013). Moreover, they need to be systematically updated while new methods of food adulteration appear all the time. A range of sophisticated tools and continuing research effort are applied to address emerging food quality issues and to ensure brand and consumer protection (Grundy, et al., 2012). 
However, new self-authentication methods addressed to consumers are also being developed. The concept of giving consumers a device for adulteration detection in food stores is of interest to risk management experts and has matured in recent years (Charlebois et al., 2016). The widespread popularity of smart phones enable the use of self-authentication methods. The device is not ready yet, but this is a subject of ongoing work. Charlebois et al. (2016) have done an exploratory study and conducted a survey among 105 consumers in the city of Innsbruck, Austria in 2015. The study, inter alia, assessed the level of interest in self-authentication. Results of the study suggest that mistrust in the food industry and regulators are directly and positively related to consumers' willingness to use a technology to authenticate food labels. Anyway, it seems to be a question of time before such a device is both financially affordable and accurate. For sure, consumers capable of testing some aspects of food authenticity may impose additional pressure on the food industry to become more disciplined (Charlebois et al., 2016).

Some technical instruments for traceability have already been in the hands of consumers. The ability to check food safety by consumers themselves has become a reality by tagging products with RFID or bar codes that can be read with a mobile phone. Traceability is applied as a tool to assist in the assurance of food safety and quality as well as to achieve consumer confidence in food authenticity, and to connect producers and consumers (Aung and Chang, 2014). An example of such a tool is a phone application named 'Pola' that helps to assess how much the investigated food producer is Polish. The application enables a consumer to find out information about a producer by scanning the bar code. 'Pola' gives each producer from zero to 100 points, 35 of which are given for Polish capital, next 10 points - for being registered in Poland, the following 30 points - for producing in Poland, next 15 points - for hiring Polish R and $\mathrm{D}$ employees, and the remaining 10 points - for not being a part of a global concern (https://www. pola-app.pl/). The idea of 'Pola' application is to promote Polish local food.

The complexity of the problem of confirming food authenticity depends a lot on the country of origin. A good example for that is Australia. It is a challenge to validate a country of origin for Australian food products and beverages (e.g. wine) because it is a large country, where the climate ranges from tropical, through desert, to Mediterranean and Alpine (Walker, 2017). Poland is a small European country where the climate is mostly temperate and rather undifferentiated throughout the whole territory so food authentication process (including analytical methods) concerning the country of origin should be relatively easy.

The results of ensuring authenticity of foodstuffs are more or less economic. Consumer's perception of food quality seems to be determined also by his/her trust in authenticity of foodstuffs. Authenticity of foodstuffs can be used as an element of marketing. Offering authentic foods can be an important source of financial gain.

The definition of authentic foodstuffs is getting broader in Polish literature. Śmiechowska suggests underlining the authenticity of regional and traditional food (Śmiechowska, 2014). This food market development meets the spread of global food. Regional and traditional food is connected with ethnic, organic and slow food. Regional and traditional food is an element of cultural heritage and culinary identity of particular regions and can be a source of regional development. The Regulation EU No 1151/2012 introduced the EU Protected Food Name Scheme (EUPFN) covering three designated indications of provenance for regional products: (1) Protected Geographic Indication (PGI) which designates products where at least one stage of production, processing or preparation takes place within the geographical area and the product has a reputation, features or certain qualities attributable to that area; (2) Protected Designation of Origin (PDO) which identifies agricultural products and foods which are produced, processed and prepared in the same geographic area; (3) Traditional Speciality Guaranteed (TSG) which identifies traditional products on account of recipe/production method/customary names etc. and have features which distinguish them from other similar products.

To date, EC has registered 40 Polish products in the PDO, PGI and TSG system, and this places Poland in the eighth position among other Member States (after Italy, France, Spain, Portugal, Greece, Germany and the United Kingdom) (www.ijhar-s.gov.pl). Poland has a great potential to offer such distinct food because of its rich cultural heritage and relatively natural agricultural production space. In 2013 about 88\% of Polish farms were individual agricultural holdings with UAA smaller than 20 ha, run by Polish traditional families (CSO, 2017). Until 2004, when Polish agriculture was included within the EU Common Agricultural Policy, many of Polish farms could have not afforded to use synthetic pesticides and fertilizers. Shortage of funding used to be a common problem of Polish farmers in the nineties.

Engaging with the EUPFN Scheme is an opportunity for Polish agricultural and the associated food sector and to accelerate regional development, especially that there is a problem of depopulation of rural areas and ethnocentrism is frequently determining food consumer behaviour in Poland. Local food production growth, which often is in line with the development of rural tourism, contributes to job creation in rural areas. However, it is usually easier to find regional and traditional food from France and/or Italy than domestic ones. The point is to make Polish traditional and regional food accessible and to 
promote it (Wiśniewska and Šavrina, 2016) so that it can become an effective tool of regional development.

In the time of growing consumer consciousness regarding their diet, while numerous food scandals are taking place all over the world, it can be expected that authenticity of food will become a value and some food companies will build their competitive advantage on it.

\section{Students' understanding of food} fraud/adulteration and authenticity issues

The results of the survey which allow to evaluate the students' perception and knowledge about the food fraud/adulteration and authenticity issues are shown in Tab. I-VI. Tab. I summarizes the respondents' associations with the concept of 'food fraud/adulteration' in order from the most to least frequently reported. It can be assumed that a typical sophomore student of Economics Faculty at the investigated Polish university ties 'food fraud/adulteration' with offering food containing lots of chemical food additives, improperly labelled, particularly with regard to the list of ingredients. Other associations with the food fraud/adulteration issue relatively often reported by the respondents are: genetically modified, unhealthy, substitution of ingredients and wrong quality. It is obvious that genetically modified food is not, in principle, adulterated. However, it is common that Polish consumers do not trust the use of GMO in food production and put a great pressure on lawmakers to interdict the use of GMO in agricultural production. Analysing the data presented in Tab. I, it can be assumed that there is a little difference between the answers given by the students of Logistics and the students of Management. The surveyed students majoring in Management much more often tie food fraud/adulteration issue with the use of GMO than the surveyed students of Logistics. It can be a result of the fact that most of the surveyed students of Logistics attended Food Quality Management course and their knowledge about the use of GMO in food industry is greater.

Tab. II and III summarizes a wider understanding of the food fraud/adulteration issue among the respondents. A relatively big part of the surveyed students recognize the following consequences of food fraud/adulteration brought to consumers: inaccurate list of ingredients, potentially harmful food (especially for allergy sufferers) and/or

I: Associations with the concept of 'food fraud/adulteration'

\begin{tabular}{|c|c|c|c|c|c|c|}
\hline \multirow{2}{*}{$\begin{array}{c}\text { Associations with the concept of ,food } \\
\text { fraud/adulteration' reported by } \\
\text { the respondents }\end{array}$} & \multicolumn{2}{|c|}{$\begin{array}{l}\text { Students of Logistics } \\
(49)\end{array}$} & \multicolumn{2}{|c|}{$\begin{array}{c}\text { Students of } \\
\text { Management (78) }\end{array}$} & \multicolumn{2}{|c|}{ Sum of responses } \\
\hline & $\begin{array}{l}\text { Number of } \\
\text { responses }\end{array}$ & $(\%)$ & $\begin{array}{l}\text { Number of } \\
\text { responses }\end{array}$ & $(\%)$ & $\begin{array}{l}\text { Number of } \\
\text { responses }\end{array}$ & (\%) \\
\hline $\begin{array}{l}\text { Containing preservatives/lots of } \\
\text { chemical food additives }\end{array}$ & 14 & 28,6 & 23 & 29,5 & 37 & 29,1 \\
\hline GMO & 2 & 4,1 & 28 & 35,9 & 30 & 23,6 \\
\hline Unhealthy & 12 & 24,5 & 16 & 20,5 & 28 & 22,0 \\
\hline $\begin{array}{l}\text { Replacement of food ingredients with } \\
\text { less expensive substitutes }\end{array}$ & 11 & 22,4 & 15 & 19,2 & 26 & 20,5 \\
\hline Possibly harmful & 6 & 12,2 & 13 & 16,7 & 19 & 15,0 \\
\hline Scam, theft, jail & 8 & 16,3 & 10 & 12,8 & 18 & 14,2 \\
\hline Counterfeited & 5 & 10,2 & 10 & 12,8 & 15 & 11,8 \\
\hline Cheaper & 6 & 12,2 & 7 & 9,0 & 13 & 10,2 \\
\hline Modified/improper food & 3 & 6,1 & 7 & 9,0 & 10 & 7,9 \\
\hline Misleading the consumer & 4 & 8,2 & 6 & 7,7 & 10 & 7,9 \\
\hline $\begin{array}{l}\text { Containing unacceptable substances, } \\
\text { contaminated }\end{array}$ & 4 & 8,2 & 5 & 6,4 & 9 & 7,1 \\
\hline
\end{tabular}

Source: own survey. 
II: Students' opinion about consequences of food fraud/adulteration to a consumer

\begin{tabular}{|c|c|c|c|c|c|c|}
\hline \multirow{2}{*}{$\begin{array}{l}\text { 'What does food fraud/adulteration } \\
\text { bring to a consumer?' }\end{array}$} & \multicolumn{2}{|c|}{$\begin{array}{c}\text { Students of Logistics } \\
(49)\end{array}$} & \multicolumn{2}{|c|}{$\begin{array}{c}\text { Students of } \\
\text { Management (78) }\end{array}$} & \multicolumn{2}{|c|}{ Sum of responses } \\
\hline & $\begin{array}{l}\text { Number of } \\
\text { responses }\end{array}$ & $(\%)$ & $\begin{array}{l}\text { Number of } \\
\text { responses }\end{array}$ & $(\%)$ & $\begin{array}{l}\text { Number of } \\
\text { responses }\end{array}$ & $(\%)$ \\
\hline Inaccurate list of ingredients & 18 & 36,7 & 27 & 34,6 & 45 & 35,4 \\
\hline $\begin{array}{l}\text { Potentially harmful (especially for } \\
\text { allergy sufferers) }\end{array}$ & 21 & 42,9 & 24 & 30,8 & 45 & 35,4 \\
\hline Consumer cheating & 10 & 20,4 & 20 & 25,6 & 30 & 23,6 \\
\hline Lower quality & 12 & 24,5 & 10 & 12,8 & 22 & 17,3 \\
\hline Lack of consumer confidence & 7 & 14,3 & 9 & 11,5 & 16 & 12,6 \\
\hline Omission of information & 5 & 10,2 & 10 & 12,8 & 15 & 11,8 \\
\hline $\begin{array}{l}\text { Replacement of food ingredients with } \\
\text { lower quality substitutes (causing } \\
\text { a difference in taste and nutritional value) }\end{array}$ & 3 & 6,1 & 11 & 14,1 & 14 & 11,0 \\
\hline Overpriced product & 5 & 10,2 & 8 & 10,3 & 13 & 10,2 \\
\hline Enhanced with lots of preservatives & 2 & 4,1 & 9 & 11,5 & 11 & 8,7 \\
\hline Incompatible with the standards & 5 & 10,2 & 5 & 6,4 & 10 & 7,9 \\
\hline No information on potential allergens & 4 & 8,2 & 5 & 6,4 & 9 & 7,1 \\
\hline $\begin{array}{l}\text { Loss of consumer trust in brand and } \\
\text { producer }\end{array}$ & 0 & 0,0 & 9 & 11,5 & 9 & 7,1 \\
\hline Lower price & 4 & 8,2 & 3 & 3,8 & 7 & 5,5 \\
\hline $\begin{array}{l}\text { Intentional misleading a consumer by } \\
\text { marketing activities }\end{array}$ & 2 & 4,1 & 5 & 6,4 & 7 & 5,5 \\
\hline Misleading name of the product & 3 & 6,1 & 3 & 3,8 & 6 & 4,7 \\
\hline $\begin{array}{l}\text { Risk of consumption of not fresh } \\
\text { product }\end{array}$ & 2 & 4,1 & 4 & 5,1 & 6 & 4,7 \\
\hline $\begin{array}{l}\text { Loss of producer and/or distributor } \\
\text { reputation }\end{array}$ & 3 & 6,1 & 3 & 3,8 & 6 & 4,7 \\
\hline
\end{tabular}

Source: own survey.

III: Students'opinion about consequences of food fraud/adulteration to a producer

\begin{tabular}{|c|c|c|c|c|c|c|}
\hline \multirow{2}{*}{$\begin{array}{c}\text { 'What does food fraud/adulteration } \\
\text { bring to a producer?' }\end{array}$} & \multicolumn{2}{|c|}{$\begin{array}{c}\text { Students of Logistics } \\
(49)\end{array}$} & \multicolumn{2}{|c|}{$\begin{array}{c}\text { Students of } \\
\text { Management (78) }\end{array}$} & \multicolumn{2}{|c|}{ Sum of responses } \\
\hline & $\begin{array}{l}\text { Number of } \\
\text { responses }\end{array}$ & $(\%)$ & $\begin{array}{l}\text { Number of } \\
\text { responses }\end{array}$ & $(\%)$ & $\begin{array}{l}\text { Number of } \\
\text { responses }\end{array}$ & $(\%)$ \\
\hline $\begin{array}{l}\text { Lowering costs of production (e.g. by } \\
\text { substitution) }\end{array}$ & 15 & 30,6 & 41 & 52,6 & 56 & 44,1 \\
\hline Higher economic gain & 16 & 32,7 & 24 & 30,8 & 40 & 31,5 \\
\hline $\begin{array}{l}\text { Loss of image/reputation/brand } \\
\text { position }\end{array}$ & 6 & 12,2 & 12 & 15,4 & 18 & 14,2 \\
\hline Consumer cheating & 7 & 14,3 & 11 & 14,1 & 18 & 14,2 \\
\hline $\begin{array}{l}\text { A risk of negative results of official food } \\
\text { control (including fines) }\end{array}$ & 5 & 10,2 & 5 & 6,4 & 10 & 7,9 \\
\hline Loss of customers & 3 & 6,1 & 7 & 9,0 & 10 & 7,9 \\
\hline $\begin{array}{l}\text { More preservatives, longer shelf life, } \\
\text { lower costs of storage }\end{array}$ & 3 & 6,1 & 7 & 9,0 & 10 & 7,9 \\
\hline Lack of credibility & 6 & 12,2 & 3 & 3,8 & 9 & 7,1 \\
\hline Increased sales volume & 4 & 8,2 & 5 & 6,4 & 9 & 7,1 \\
\hline Higher efficiency & 4 & 8,2 & 4 & 5,1 & 8 & 6,3 \\
\hline $\begin{array}{l}\text { Momentary profit, may lead to } \\
\text { bankruptcy }\end{array}$ & 3 & 6,1 & 4 & 5,1 & 7 & 5,5 \\
\hline Shorter production process & 3 & 6,1 & 4 & 5,1 & 7 & 5,5 \\
\hline $\begin{array}{l}\text { Taking advantage of consumer } \\
\text { unawareness }\end{array}$ & 3 & 6,1 & 3 & 3,8 & 6 & 4,7 \\
\hline
\end{tabular}

Source: own survey. 
cheating on consumers. According to $30-40 \%$ of the respondents, food producers lower their costs of production (e.g. by substitution) and make a bigger profit thanks to food fraud/adulteration. Slightly over $20 \%$ of the respondents mention loss of image/reputation/brand position and lack of credibility as consequences of food fraud/adulteration for the fraudsters. Looking for the differences between the answers of students of Logistics and students of Management it can be noticed that students of Logistics more frequently see the problem with lower quality of fraudulent food. On the other hand students of Management more frequently indicate the problem of replacement of food ingredients with lower quality substitutes causing a difference in taste and nutritional value. Summing up, both groups of students see the problem with low quality of fraudulent food but they express it with different words. A similar situation is when it comes to detecting a difference between the answers of the surveyed groups of students regarding consequences involving 'loss of consumer trust in brand and producer' and 'lack of credibility of the producer'. It happened quite often that the same problems were attributed to consumers and producers by the respondents.

Tab. IV summarizes the respondents' associations with the term 'authentic food product' in order from the most to least frequently reported. It can be assumed that a typical sophomore student of Economics Faculty at the researched university associates 'authentic food product' with healthy/healthier, correctly labelled, better quality and genuine food product. However, the surveyed students of Logistics associate better quality with authentic food products more frequently. If we sum up the respondents' connotations such as 'genuine', 'true' and 'reliable', it will turn out that $32 \%$ of the surveyed students of Logistics and $33 \%$ of the surveyed students of Management have such associations with food authenticity. The surveyed students of Logistics more frequently pay attention to the fact that authentic foodstuffs may be more expensive. Only about $5 \%$ of the surveyed students tie the idea of authentic food with traditional/regional/rural food.

The students' statements about the consequences of food authenticity presented in Tab. V and 6 are quite diversified. According to $20-23 \%$ of the respondents, ensuring authenticity of food gives a consumer a safe product and reliable composition of product. 14-17\% of the surveyed students associate food authenticity with healthy/healthier eating, consumer's consciousness about his/her food choices and better quality. Up to $18-21 \%$ of the surveyed students claim that ensuring

IV: Associations with the term 'authentic food product'

\begin{tabular}{|c|c|c|c|c|c|c|}
\hline \multirow{2}{*}{$\begin{array}{l}\text { Associations with the term } \\
\text { 'authentic food product' }\end{array}$} & \multicolumn{2}{|c|}{$\begin{array}{c}\text { Students of Logistics } \\
(49)\end{array}$} & \multicolumn{2}{|c|}{$\begin{array}{c}\text { Students of } \\
\text { Management (78) }\end{array}$} & \multicolumn{2}{|c|}{ Sum of responses } \\
\hline & $\begin{array}{l}\text { Number of } \\
\text { responses }\end{array}$ & $(\%)$ & $\begin{array}{l}\text { Number of } \\
\text { responses }\end{array}$ & $(\%)$ & $\begin{array}{l}\text { Number of } \\
\text { responses }\end{array}$ & $(\%)$ \\
\hline 1.Healthy, healthier & 17 & 34,7 & 29 & 37,2 & 46 & 36,2 \\
\hline 2. Correctly labelled & 13 & 26,5 & 20 & 25,6 & 33 & 26,0 \\
\hline 3. Better quality & 16 & 32,7 & 17 & 21,8 & 33 & 26,0 \\
\hline 4. Genuine & 7 & 14,3 & 18 & 23,1 & 25 & 19,7 \\
\hline 5. Prepared from natural ingredients & 8 & 16,3 & 11 & 14,1 & 19 & 15,0 \\
\hline 6. Good & 6 & 12,2 & 9 & 11,5 & 15 & 11,8 \\
\hline 7. More expensive & 8 & 16,3 & 7 & 9,0 & 15 & 11,8 \\
\hline 8. Organic & 5 & 10,2 & 8 & 10,3 & 13 & 10,2 \\
\hline 9. Of standard value & 4 & 8,2 & 8 & 10,3 & 12 & 9,4 \\
\hline 10. Truth & 7 & 14,3 & 5 & 6,4 & 12 & 9,4 \\
\hline 11. Reliable & 2 & 4,1 & 10 & 12,8 & 12 & 9,4 \\
\hline 12. Up to legal provisions/industry standards & 9 & 18,4 & 3 & 3,8 & 12 & 9,4 \\
\hline 13. Safe/harmless & 4 & 8,2 & 8 & 10,3 & 12 & 9,4 \\
\hline 14. Fresh & 6 & 12,2 & 4 & 5,1 & 10 & 7,9 \\
\hline 15. Readable and legible label & 2 & 4,1 & 7 & 9,0 & 9 & 7,1 \\
\hline 16. No preservatives/artificial colours & 3 & 6,1 & 6 & 7,7 & 9 & 7,1 \\
\hline 17. Tasty & 4 & 8,2 & 4 & 5,1 & 8 & 6,3 \\
\hline 18. Certified quality & 4 & 8,2 & 4 & 5,1 & 8 & 6,3 \\
\hline 19. Unquestionable & 4 & 8,2 & 3 & 3,8 & 7 & 5,5 \\
\hline 20. Traditional/regional/rural food & 4 & 8,2 & 2 & 2,6 & 6 & 4,7 \\
\hline 21. Price adequate to quality & 1 & 2,0 & 5 & 6,4 & 6 & 4,7 \\
\hline 22. Nutrient & 3 & 6,1 & 3 & 3,8 & 6 & 4,7 \\
\hline
\end{tabular}

Source: own survey. 
V: Students' opinion about the consequences of authenticity of food to a consumer

\begin{tabular}{|c|c|c|c|c|c|c|}
\hline \multirow{2}{*}{$\begin{array}{l}\text { 'What does authenticity of } \\
\text { food bring to a consumer?' }\end{array}$} & \multicolumn{2}{|c|}{$\begin{array}{c}\text { Students of Logistics } \\
(49)\end{array}$} & \multicolumn{2}{|c|}{$\begin{array}{c}\text { Students of } \\
\text { Management (78) }\end{array}$} & \multicolumn{2}{|c|}{ Sum of responses } \\
\hline & $\begin{array}{l}\text { Number of } \\
\text { responses }\end{array}$ & $(\%)$ & $\begin{array}{l}\text { Number of } \\
\text { responses }\end{array}$ & $(\%)$ & $\begin{array}{l}\text { Number of } \\
\text { responses }\end{array}$ & $(\%)$ \\
\hline 1. Safe product & 9 & 18,4 & 21 & 26,9 & 30 & 23,6 \\
\hline 2. Reliable composition of product & 13 & 26,5 & 13 & 16,7 & 26 & 20,5 \\
\hline 3. Healthy/healthier eating & 8 & 16,3 & 14 & 17,9 & 22 & 17,3 \\
\hline 4. Consumer knows what he buys and eats & 8 & 16,3 & 12 & 15,4 & 20 & 15,7 \\
\hline 5. Better quality & 7 & 14,3 & 11 & 14,1 & 18 & 14,2 \\
\hline $\begin{array}{l}\text { 6. An increase in confidence in } \\
\text { the producer }\end{array}$ & 3 & 6,1 & 12 & 15,4 & 15 & 11,8 \\
\hline 7. Correctly labelled, as described & 7 & 14,3 & 6 & 7,7 & 13 & 10,2 \\
\hline $\begin{array}{l}\text { 8. No/much less chemical food } \\
\text { additives, natural product }\end{array}$ & 1 & 2,0 & 10 & 12,8 & 11 & 8,7 \\
\hline 9. Higher prices & 4 & 8,2 & 6 & 7,7 & 10 & 7,9 \\
\hline 10. Conscious choice & 1 & 2,0 & 8 & 10,3 & 9 & 7,1 \\
\hline 11. Reliable & 3 & 6,1 & 4 & 5,1 & 7 & 5,5 \\
\hline 12. Worth the money & 1 & 2,0 & 6 & 7,7 & 7 & 5,5 \\
\hline 13. Environmentally friendly/organic & 1 & 2,0 & 5 & 6,4 & 6 & 4,7 \\
\hline 14. Guaranteed quality & 2 & 4,1 & 4 & 5,1 & 6 & 4,7 \\
\hline
\end{tabular}

Source: own survey.

VI: Students' opinion about the consequences of authenticity of food to a producer

\begin{tabular}{|c|c|c|c|c|c|c|}
\hline \multirow{2}{*}{$\begin{array}{l}\text { 'What does authenticity of food } \\
\text { ensuring bring to a producer?' }\end{array}$} & \multicolumn{2}{|c|}{$\begin{array}{c}\text { Students of Logistics } \\
(49)\end{array}$} & \multicolumn{2}{|c|}{$\begin{array}{c}\text { Students of } \\
\text { Management (78) }\end{array}$} & \multicolumn{2}{|c|}{ Sum of responses } \\
\hline & $\begin{array}{l}\text { Number of } \\
\text { responses }\end{array}$ & $(\%)$ & $\begin{array}{l}\text { Number of } \\
\text { responses }\end{array}$ & $(\%)$ & $\begin{array}{l}\text { Number of } \\
\text { responses }\end{array}$ & $(\%)$ \\
\hline 1. Higher costs of production & 11 & 22,4 & 15 & 19,2 & 26 & 20,5 \\
\hline $\begin{array}{l}\text { 2. Greater confidence in the producer } \\
\text { and its products }\end{array}$ & 10 & 20,4 & 13 & 16,7 & 23 & 18,1 \\
\hline $\begin{array}{l}\text { 3. Good public opinion about } \\
\text { the producer }\end{array}$ & 9 & 18,4 & 14 & 17,9 & 23 & 18,1 \\
\hline 4. Gaining loyal customers & 10 & 20,4 & 13 & 16,7 & 23 & 18,1 \\
\hline 5. Brand building & 7 & 14,3 & 12 & 15,4 & 19 & 15,0 \\
\hline 6. Greater credibility of the producer & 7 & 14,3 & 10 & 12,8 & 17 & 13,4 \\
\hline 7. Higher economic gain & 4 & 8,2 & 8 & 10,3 & 12 & 9,4 \\
\hline $\begin{array}{l}\text { 8. Caring about current and future } \\
\text { customers }\end{array}$ & 4 & 8,2 & 6 & 7,7 & 10 & 7,9 \\
\hline 9. Offering high quality products & 3 & 6,1 & 7 & 9,0 & 10 & 7,9 \\
\hline 10. More customers & 1 & 2,0 & 7 & 9,0 & 8 & 6,3 \\
\hline 11. Giving true information to consumers & 3 & 6,1 & 3 & 3,8 & 6 & 4,7 \\
\hline 12. Bigger sale & 1 & 2,0 & 5 & 6,4 & 6 & 4,7 \\
\hline 13. Respect of consumers & 2 & 4,1 & 4 & 5,1 & 6 & 4,7 \\
\hline 14. Operating transparently and honestly & 0 & 0,0 & 6 & 7,7 & 6 & 4,7 \\
\hline
\end{tabular}

Source: own survey.

authenticity of food by a producer costs him more, builds a greater confidence in the producer and its products, earns the producer good public reputation and helps to gain loyal customers. When it comes to indicating the biggest differences between the opinions of students of Logistics and students of Management about the implications of ensuring authenticity of food for consumers and producers, it has to be said that the consequences which are less frequently mentioned differ. 


\section{DISCUSSION}

The research was an attempt to collate and conceptualize the food fraud/adulteration and authenticity issues on the grounds of the literature, regulatory and industry standards review and a survey conducted among students of Economics Faculty. Not so long ago, both EU and US food business operators were required to assess and control potential food hazards mainly on the basis of principles used to develop HACCP. Whereas HACCP is recognized as an effective tool against accidental contamination appearing along the entire food supply chain, FSSC 22000, HARPC, TACCP and other HACCP-based standards are developed to prevent, detect, combat and mitigate food fraud and/or food terrorists' actions. Food managers are encouraged to use new methods and tools covering deliberate adulteration of food since food supply chains are more and more vulnerable to fraud and terrorist attacks as a result of globalization and liberalization of trade, growing anonymity of people running food businesses, market pressure to reduce food prices, scientific and technological progress advantageous to fraudsters and so on (Kowalczyk, 2016). Analysing other circumstances of growing popularity of food industry standards with regard to fraud and other forms of deliberate actions can be the object of future research. It is worth underlining that there is non-uniformity of the definitions of food adulteration around the world, especially in terms of intentionality of the action. Polish legislator considers both intentional and unintentional actions as adulteration (SAC, 2013) and it is not in step with other definitions (Kowalska, Soon and Manning, 2018; Spink and Moyer, 2013; Manning and Soon, 2016; Silvis et al., 2017). Thus, the need of developing one common definition of food adulteration within Member States is emerging.
The exploratory research has added to our knowledge of students' perception of food fraud/adulteration and authenticity issues and their implications for consumers and producers. The investigated students have a general sense of researched issues even if most of them, substantially, have not learned about these problems at the university. However, one third of the respondents claim that fraudulent food contain lots of chemical additives, and it is hard to agree with that. Little differences of students' perception of food fraud/adulteration and authenticity between the two surveyed groups of people may be a result of different syllabuses of Logistics and Management, where other issues are emphasized.

There are some limitations to this study in terms of the size of the sample group thus this limits wider generalisation to the population of students of business majors in Poland. It should be underlined that students of business majors most probably have different perception of food fraud/adulteration and food authenticity issues than students of humanities or engineering majors. Since food fraud is increasingly important economic issue, the idea of including food fraud course in university programme for business majors seems to be justified. Future research should look to expand this study to encompass larger and more diversified group of consumers and food business managers. Although, the findings about students' perception of food issues would help to develop effective information and/or education measures for adulterated food and promotion measures for authentic foodstuffs. There is a need to constantly inform consumers about fraudulent practices whether through websites of relevant institutions or the media (Koubová, Samková and Hasonová, 2018).

\section{CONCLUSION}

The conceptualisation of researchedissues allow us to conclude that the concept of 'authenticfood'may be more less treated as contrary to 'food fraud/adulteration'. Ensuring authentic food products may be a significant source of a producer's competitive advantage. Preventing, controlling and mitigating food fraud effectively help to protect consumers' interests (in terms of health and economic safety) and build their trust in food. The analysis of collected data shows that surveyed students' understanding of the phenomenon and its consequences is quite appropriate. However, other author's studies show that Polish consumers are not familiar enough with the problem of food fraud/adulteration and state control institutions' activities in this field. The proposition is to conduct a social campaign covering food fraud/adulteration phenomenon and to include food fraud, authenticity and other aspects of food integrity issue in university program developed for various majors. Knowledgeable consumers may impose additional pressure on the food industry to become more disciplined.

\section{Acknowledgment}

The author is grateful to the students for their participation in the survey and their contribution to the creation of new food fraud course.

\section{REFERENCES}

AUNG, M. M. and CHANG, Y. S. 2014. Traceability in a food supply chain: Safety and quality perspectives. Food Control, 39: 172-184. 
BSI. 2014. Guide to protecting and defending food and drink from deliberate attack. PAS 96:2014. $3^{\text {rd }}$ Edition. The British Standards Institution.

CAVIN, CH., COTTENT, G., BLANCPAIN, C., BESSAIRE, T., FRANK, N. and ZBINDEN, P. 2016. Food Adulteration: From Vulnerability Assessment to New Analytical Solutions. Chimia, 70(5): 329-333.

CENTRAL STATISTICAL OFFICE. 2017. Statistical Yearbook of Agriculture 2016. Statistical Information and Elaborations. [Online]. Warsaw: CSO. Available at: https://stat.gov.pl/en/topics/statistical-yearbooks/ statistical-yearbooks/statistical-yearbook-of-agriculture-2016,6,11.html [2018, January 15].

CHARLEBOIS, S., SCHWAB, A., HENN, R. and HUCK, CH.W. 2016. Food fraud: An exploratory study for measuring consumer perception towards mislabelled food products and influence on self-authentication intentions. Trends in Food Science $\%$ Technology, 50: 211-218.

DAVIDSON, R. K., ANTUNES, A., MADSLIEN, E. H., BELENGUER, J., GEREVINI, M., PEREZ, T.T. and PRUGGER, R. 2017. From food defence to food supply chain integrity. British Food Journal, 119(1): 52-66.

EUROPEAN COMMISSION. 2013. EC Directorate General for Health and Consumers, Scoping study Delivering on EU food safety and nutrition in 2050 - Scenarios of future change and policy responses, Framework Contract for evaluation and evaluation related services - Lot 3: Food Chain. Final Report. [Online]. Brussels: European Commission. Available at: https://ec.europa.eu/food/sites/food/files/safety/docs/final_report_scoping_study_en.pdf [Accessed: 2017, March 15].

EUROPEAN COMMISSION. 2016. The EU Food Fraud Network and the System for Administrative Assistance $\sigma$ Food Fraud. Annual report 2016. [Online]. Brussels: European Commission. Available at: https://ec.europa.eu/ food/sites/food/files/safety/docs/food-fraud_network_activity_report_2016.pdf [Accessed: 2017, June 8].

EU. 2012. Regulation (EU) No 1151/2012 of the European Parliament and of the Council of 21 November 2012 on quality schemes for agricultural products and foodstuffs. In: Official Journal of the European Union, L 343/1, 14. 12. 2012. Available at: https://eur-lex.europa.eu/legal-content/EN/TXT/ PDF/?uri=CELEX:32012R1151\&from=en

EU. 2011. Regulation (EU) No 1169/2011 of the European Parliament and of the Council of 25 October 2011 on the provision of food information to consumers, amending Regulations (EC) No 1924/2006 and (EC) No 1925/2006 of the European Parliament and of the Council, and repealing Commission Directive 87/250/EEC, Council Directive 90/496/EEC, Commission Directive 1999/10/EC, Directive 2000/13/EC of the European Parliament and of the Council, Commission Directives 2002/67/EC and 2008/5/EC and Commission Regulation (EC) No 608/2004. In: Official Journal of the European Union, L 304/18, 22.11.2011. Available at:https://eur-lex.europa.eu/legal-content/EN/TXT/PDF/?uri=CELEX:32011R1169\&from=EN

GROVER, A. K., CHOPRA, S. and MOSHER, G. A. 2016. Food safety modernization act: A quality management approach to identify and prioritize factors affecting adoption of preventive controls among small food facilities. Food Control, 66: 24l-249.

GRUNDY, H. H., KELLY, S. D., CHARLTON, A. J., DONARSKI, J. A., HIRD, S. J., HIRD, H. J. and COLLINS, M. J. 2012. Food Authenticity and Food Fraud Research: Achievements and Emerging Issues. Journal of the Association of Public Analysts, 40: 65-68.

HINES, T. and MURPHY, L. 2016. Combatting Food Fraud With Intelligent Due Diligence. World Food Regulation Review, 25(8): 20-23.

JOHNSON, R. 2014. Food Fraud and "Economically Motivated Adulteration" of Food and Food Ingredients. [Online]. Congressional Research Service. Available at: https:/fas.org/sgp/crs/misc/R43358.pdf [Accessed: 2018, April 12].

KOUBOVÁ, J., SAMKOVÁ, E. and HASONOVÁ, L. 2018. Food fraud detection by Czech Agricultural and Food Inspection Authority in retail market. British Food Journal, 120(4): 930-938.

KOWALCZYK, S. 2016. Food safety and quality [in Polish: Bezpieczeństwo i jakośćżywności]. Warsaw: PWN SA.

KOWALSKA, A., SOON, J.M. and MANNING, L. 2018. A study on adulteration in cereals and bakery products from Poland. Food Control, (92): 348-356.

LEONARDO, R., NUNES, R. S. C., MONTEIRO, M. L. G., CONTE-JUNIOR, C. A., DEL AGUILAA, E. M. and PASCHOALIN, V. M. F. 2016. Molecular testing on sardines and rulings on the authenticity and nutritional value of marketed fishes: An experience report in the state of Rio de Janeiro, Brazil. Food Control, 60: 394-400.

LIPP, M. 2011. A Closer Look at Chemical Contamination. Food Safety Magazine. [Online]. Available at: http:// www.foodsafetymagazine.com/magazine-archivel/augustseptember-2011/a-closer-look-at-chemicalcontamination/ [Accessed: 2015, December 28].

MANNING, L. 2017. Food integrity. British Food Journal, 119(1): 2-6.

MANNING, L. and SOON, J. M. 2016. Food Safety, Food Fraud, and Food Defence: A Fast Evolving Literature. Journal of Food Science, 81(4): 823-834.

MARVIN, H. J. P., BOUZEMBRAK, Y., JANSSEN, E. M., VAN DER FELS- KLERX, H. J., VAN ASSELT, E. D. and KLETER, G. A. 2016. A holistic approach to food safety risks: Food fraud as an example. Food Research International, 89(1): 463-470.

MOYER, D. C., DEVRIES, J. W. and SPINK, J. 2017. The economics of a food fraud incident - Case studies and examples including Melamine in Wheat Gluten. Food Control, 71: 358-364. 
POLAND. 2000. The Act on the Commercial Quality of Agricultural and Food Products as of December 21, 2000. In: Journal of Laws of the Republic of Poland. 2000, No 5, item 44, as amended. Available at: http://prawo.sejm.gov.pl/isap.nsf/download.xsp/WDU20010050044/U/D20010044Lj.pdf

POLAND. 2006. The Act on the Safety of Food and Nutrition as of August 25, 2006. In: Journal of Laws of the Republic of Poland. 2006, No 171, item 1225, as amended. Available at: http://prawo.sejm.gov.pl/isap.nsf/ download.xsp/WDU20061711225/U/D20061225Lj.pdf

PRICE WATERHOUSE COOPERS. 2017. Food Fraud Vulnerability Assessment and Mitigation. Are you doing enough to prevent food fraud? [Online]. Available at: https://www.pwccn.com/en/migration/pdf/fsis-food-fraudnov2016.pdf [Accessed: 2018, September 10].

SUPREME ADMINISTRATIVE COURT. 2013. The Judgment of 6 February 2013 in Case the liability for placing adulterated butter on the market. II GSK 2171/11.

SHEARS, P. 2010. Food Fraud - A Current Issue but an Old Problem. British Food Journal, 112(2): 198-213.

SILVIS, I. C. J., VAN RUTH, S. M., VAN DER FELS-KLERX, H. J. and LUNING, P. A. 2017. Assessment of food fraud vulnerability in the spices chain: An explorative study. Food Control, 81: 80-87.

SPINK, J. 2014. Direction on Food Fraud and Vulnerability Assessment (VACCP). Food Fraud Initiative. [Online]. Michigan state University. Available at: http:/ffoodfraud.msu.edu/2014/05/08/gfsi-direction-onfood-fraud-and-vulnerability-assessment-vaccp/ [Accessed: 2016, August 12].

SPINK, J. 2016. MSU FFI Report. Review - New FSSC 22000 Version 4 Regarding Food Fraud and Food Defence. [Online]. Available at: http:/ffoodfraud.msu.edu/wp-content/uploads/2016/12/MSU-FFTTFFIR-FSSC-22000-update-Edition-4-2017-v8-b.pdf [Accessed: 2017, January 12].

SPINK, J. and MOYER, D. C. 2011. Defining the Public Health Threat of Food Fraud. Journal of Food Science, 76(9): 157-163.

SPINK, J. and MOYER, D.C. 2013. Understanding and Combating Food Fraud. Food Technology, 67(1): 30-35.

SPINK, J., MOYER, D. C. and SPEIER-PERO, C. 2016. Introducing the Food Fraud Initial Screening model (FFIS). Food Control, 69: 306-314.

SPINK, J., ORTEGA, D. L., CHEN, C. and WU, F. 2017. Food fraud prevention shifts the food risk focus to vulnerability. Trends in Food Science $\sigma$ Technology, 62: 215-220.

ŚMIECHOWSKA, M., 2014. Ensuring authenticity and reliability of regional and traditional products [in Polish:Zapewnienie autentyczności i wiarygodności produktom regionalnym i tradycyjnym]. Annals of the Polish Association of Agricultural and Agribusiness Economists, 16(3): 282-287.

VINCI, G., PRETI, R., TIERI, A. and VIE, S. 2013. Authenticity and quality of animal origin food investigated by stable-isotope ratio analysis. Journal of the Science of Food and Agriculture, 93(3): 439-448.

WALKER, G. S. 2017. Food authentication and traceability: An Asian and Australian perspective. Food Control, 72: 168-172.

WANG, C., VAN FLEET, D. D. and MISHRA, A.K. 2017. Food integrity: a market-based solution. British Food Journal, 119(1): 7-19.

WIŚNIEWSKA, M. Z. and ŠAVRINA, B. 2016. The Latvian system of shaping the quality of life and culinary identity [in Polish: Łotewski system kształtowania jakości życia i tożsamości kulinarnej]. Problems of Quality, 7-8: 42-49. 